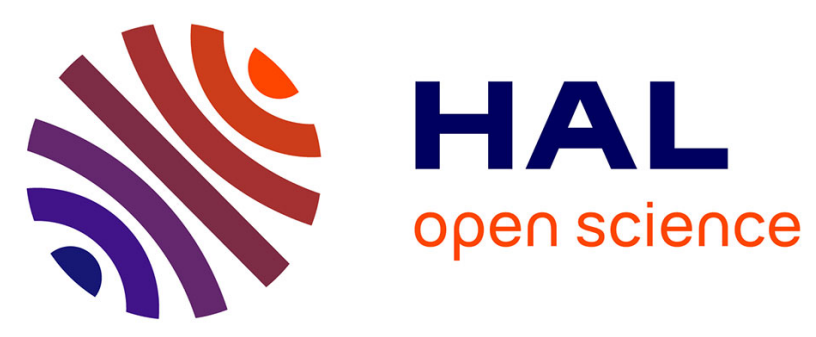

\title{
Perinatal exposure to chlordecone, thyroid hormone status and neurodevelopment in infants: The Timoun cohort study in Guadeloupe (French West Indies).
}

Sylvaine Cordier, Emilie Bouquet, Charline Warembourg, Catherine Massart, Florence Rouget, Philippe Kadhel, Henri Bataille, Christine Monfort, Olivier Boucher, Gina Muckle, et al.

\section{To cite this version:}

Sylvaine Cordier, Emilie Bouquet, Charline Warembourg, Catherine Massart, Florence Rouget, et al.. Perinatal exposure to chlordecone, thyroid hormone status and neurodevelopment in infants: The Timoun cohort study in Guadeloupe (French West Indies).. Environmental Research, 2015, 138C, pp.271-278. 10.1016/j.envres.2015.02.021 . hal-01134317

HAL Id: hal-01134317

https://hal-univ-rennes1.archives-ouvertes.fr/hal-01134317

Submitted on 19 May 2015

HAL is a multi-disciplinary open access archive for the deposit and dissemination of scientific research documents, whether they are published or not. The documents may come from teaching and research institutions in France or abroad, or from public or private research centers.
L'archive ouverte pluridisciplinaire HAL, est destinée au dépôt et à la diffusion de documents scientifiques de niveau recherche, publiés ou non, émanant des établissements d'enseignement et de recherche français ou étrangers, des laboratoires publics ou privés. 
Perinatal exposure to chlordecone, thyroid hormone status and neurodevelopment in infants: the Timoun cohort study in Guadeloupe (French West Indies)

Sylvaine Cordier ${ }^{\mathrm{a}}$, Emilie Bouquet ${ }^{\mathrm{a}}$, Charline Warembourg ${ }^{\mathrm{a}}$, Catherine Massart ${ }^{\mathrm{b}}$, Florence Rouget $^{\mathrm{a}, \mathrm{c}}$, Philippe Kadhel ${ }^{\mathrm{a}, \mathrm{d}}$, Henri Bataille ${ }^{\mathrm{e}}$, Christine Monfort $^{\mathrm{a}}$, Olivier Boucher ${ }^{\mathrm{f}}$, Gina Muckle $^{\text {f,g }}$, Luc Multigner ${ }^{\mathrm{a}}$

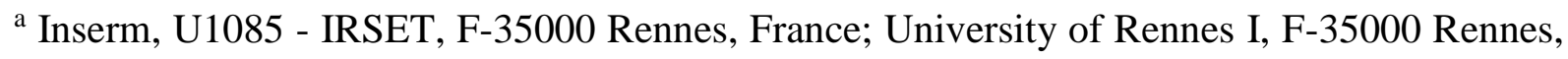
France

${ }^{\mathrm{b}}$ Laboratory of Hormonology, CIC-P INSERM 1414, CHU Rennes, F-35000 Rennes, France

${ }^{\mathrm{c}}$ Département de Pédiatrie, CHU Rennes, F-35000 Rennes, France

${ }^{\mathrm{d}}$ Pôle Parent - Enfant, Service de Gynécologie-Obstétrique, CHU Pointe-à-Pitre, BP 465, 97159, Pointe-à-Pitre, Guadeloupe.

${ }^{\text {e }}$ Centre d'Action Medico-Social, CHU Martinique, F-97292, Le Lamentin, Martinique.

${ }^{\mathrm{f}}$ Centre de recherche du Centre Hospitalier Universitaire de Québec (CHUQ), Édifice Delta

2, Bureau 600, 2875, boulevard Laurier, 6e étage, Québec (Qc), Canada, G1V 2M2.

g Université Laval, 2325, rue de l'Université, Québec (Qc), Canada, G1V 0A6.

Corresponding author: Sylvaine Cordier, Irset-Inserm UMR 1085

Campus EHESP, Bâtiment Leres

Avenue du Prof. Léon Bernard

CS74312

35043 RENNES Cedex

Tel : (+33) 0223235929

Fax : (+33) 0223235055

e-mail : sylvaine.cordier@inserm.fr

Abbreviations :

ASQ : Ages and Stages Questionnaire ; BMI: Body Mass Index; DDE: dichlorodiphenyl dichloroethylene ; DDT : dichlorodiphenyl trichloroethane; FT3: free tri-iodothyronine; FT4: free thyroxine; GAM: generalized additive model; HCB: hexachlorobenzene; IQ: Intelligence Quotient; LOD: limit of detection; PBDE: polybrominated diphenyl ethers; PCB: polychlorinated biphenyls; TSH: Thyroid stimulating hormone. 


\begin{abstract}
Background: Perinatal exposure to endocrine-disrupting chemicals may affect thyroid hormones homeostasis and impair brain development. Chlordecone, an organochlorine insecticide widely used in the French West Indies has known estrogenic and progestin properties, but no data is available, human or animal, on its action on thyroid hormone system. Objectives: Our aim was to evaluate the impact of perinatal exposure to chlordecone on the thyroid hormone system of a sample of infants from the Timoun mother-child cohort in Guadeloupe and their further neurodevelopment.
\end{abstract}

Methods: Chlordecone was measured in cord blood and breast milk samples. Thyroid stimulating hormone (TSH), free tri-iodothyronine (FT3), free thyroxine (FT4) were determined in child blood at 3 months $(n=111)$. Toddlers were further assessed at 18 months using an adapted version of the Ages and Stages Questionnaire (ASQ).

Results: Cord chlordecone was associated with an increase in TSH in boys, whereas postnatal exposure was associated with a decrease in FT3 overall, and in FT4 among girls. Higher TSH level at 3 months was positively associated with the ASQ score of fine motor development at 18 months among boys, but TSH did not modify the association between prenatal chlordecone exposure and poorer ASQ fine motor score.

Conclusions: Perinatal exposure to chlordecone may affect TSH and thyroid hormone levels at 3 months, differently according to the sex of the infant. This disruption however did not appear to intervene in the pathway between prenatal chlordecone exposure and fine motor child development.

Keywords: chlordecone, prenatal, breast feeding, thyroid hormone, children Funding sources: This work was supported by grants from the National Institute of Health and Medical Research (INSERM), the National Research Agency (ANR), the French Agency for 
Environmental and Occupational Health Safety (AFSSET), the French Ministry of Environment, and the General Health Directorate (DGS). The authors declare they have no actual or potential competing financial interests.

The research procedures were approved by the Guadeloupean Ethics Committee for biomedical studies involving human subjects (Project Nº3-04 01/10/2004). 


\section{Introduction}

Adequate maternal thyroid function in early pregnancy and adequate fetal thyroid function are essential for optimal fetal development, and subtle changes in circulating levels of thyroid hormone may have permanent effect on child development (Zoeller et al. 2002).

Thyroid disruption resulting from exposure to environmental synthetic chemicals has been documented in wildlife and experimental animals (Brucker-Davis 1998). The picture is not as clear in humans but there is concern that exposure of pregnant women and infants to endocrinedisrupting chemicals such as polychlorinated biphenyls (PCBs), dichlorodiphenyl trichloroethane (DDT) and its metabolite dichlorodiphenyl dichloroethylene (DDE), hexachlorobenzene and its metabolite pentachlorophenol, polybrominated diphenyl ethers (PBDEs), and nonylphenol may affect thyroid hormones homeostasis and impair growth and brain development (Boas et al. 2012).

Several epidemiological studies have evaluated in particular the impact of prenatal PCBs exposure on child thyroid function, mainly at birth, relying on measures of exposure to PCBs during pregnancy and measures of thyroid hormone levels in cord blood or shortly after birth (prick tests). Some have found decreasing levels of free tri-iodothyronine (FT3) and free thyroxine (FT4) (Maervoet et al. 2007) or total T4 (Herbstman et al. 2008) or increase in thyroid stimulating hormone (TSH) (Alvarez-Pedrerol et al. 2008a; Chevrier et al. 2007) in relation with prenatal PCB exposure but most have found no association (Dallaire et al. 2008, 2009; Longnecker et al. 2000; Lopez-Espinosa et al. 2010; Ribas-Fito et al. 2003; Steuerwald et al. 2000; Takser et al. 2005; Wang et al. 2005; Wilhelm et al. 2008). These contradictory findings may be partly due to the high variability of thyroid hormone levels at birth due to determinants such as gestational age, mode of delivery or neonatal health that are often not taken into account (Boas et al. 2012). When thyroid function has been evaluated among older children including 
toddlers, results regarding consequences of perinatal exposure to PCBs are more consistent. Increase in TSH level or decrease in T3 (free or total) or total T4 have been observed in most studies (Alvarez-Pedrerol et al. 2008b; Darnerud et al. 2010; Herbstman et al. 2008; Koopman et al. 1994; Osius et al. 1999), except in Matsuura et al. (2001) and Dallaire et al. (2009).

Chlordecone is an organochlorine insecticide that has intensively been used in the French West Indies from 1973 until 1993 to control banana root borers. Its persistence in the environment has resulted in a widespread contamination of soils, water sources and foodstuff (Dubuisson et al. 2007) leading to contamination of populations. Chlordecone is neurotoxic, spermatotoxic, potentially carcinogenic in humans and possesses well defined estrogenic activity (Cannon et al., 1978; Hammond et al., 1979; Multigner et al., 2010). To our knowledge no data is available, human or animal, on its thyroid effects and/or its action on thyroid hormone system.

A longitudinal mother-child study (the TIMOUN cohort) has been set up in Guadeloupe (French West Indies) to investigate the impact of perinatal environmental exposure to chlordecone on child development. In previous reports we have shown impairments of fine motor function at 18 months of age, specifically among boys (Boucher et al. 2013). Here we propose to study the association between chlordecone and thyroid hormone levels at 3 months, and the potential mediation of thyroid dysfunction, if any, on impairment of later child neurodevelopment.

\section{Methods}

\subsection{Population and Data Collection}

The TIMOUN mother-child cohort included women in the second trimester of pregnancy that planned to give birth in the University Hospital of Pointe-à-Pitre and the General Hospital of 
Basse-Terre (accounting for $70 \%$ of all deliveries in Guadeloupe) from December 2004 to December 2007. A detailed informed consent was obtained from 1068 pregnant women. The research procedures were approved by the Guadeloupean Ethics Committee for biomedical studies involving human subjects. A prenatal maternal face-to-face interview was conducted at enrolment by trained midwives to assess obstetrical, medical, personal, and socioeconomic characteristics. Maternal diseases, adverse delivery incidents as well as newborn anthropometric parameters and health information were collected at the end of pregnancy from medical records. Cord blood samples were obtained.

A subgroup of infants was examined at 3 months of age. Exclusion criteria included maternal conditions such as history of diabetes, gestational diabetes mellitus, hypertension, epilepsy, human immunodeficiency virus infection, and long-term corticotherapy $(n=263)$. Exclusion criteria for newborns $(n=230)$ were not singleton, preterm, small for gestational age, APGAR $<7$ at $5 \mathrm{~min}$, severe respiratory distress, severe icterus, severe hypoglycemia and materno-foetal infection. For the remaining 575 participants, 365 could not be contacted because of incorrect address or refusal to participate, and 62 had incomplete data. This left 148 children for this analysis. Maternal interviews were conducted at that time (3 months after birth) to assess potential confounders and breast feeding status.

\subsection{Exposure assessment}

\subsubsection{Prenatal exposure to chlordecone and other organochlorine compounds}

Cord blood sample were collected, processed and frozen at $-30^{\circ}$ until shipment on dry ice to Liege University (CART) for analysis. Chlordecone, PCB153 chosen as the representative of the whole mixture of PCBs, and p,p'-DDE were measured by gas chromatography-electron 
capture detection. Preparation of samples and the quantification method were as previously described (Multigner et al. 2010). The limit of detection (LOD) was $0.06 \mu \mathrm{g} / \mathrm{L}$ for chlordecone, and $0.05 \mu \mathrm{g} / \mathrm{L}$ for PCB-153 and $p, p$ '-DDE.

Total cholesterol and triglyceride concentrations in cord plasma samples were determined by standard enzymatic procedures (DiaSys Diagnostoc Systems GmbH; Holzheim, Germany) and total lipid concentrations were calculated as described by Bernert et al. 2007.

Among the 148 cord blood samples, the median of cord chlordecone concentrations was 0.14 $\mu \mathrm{g} / \mathrm{L}$. Due to more than $40 \%$ value <LOD and the possibility of nonlinear relation between chlordecone and thyroid hormones, we categorized cord chlordecone concentrations into 3 classes : the first corresponding to concentrations $\angle \mathrm{LOD}$ and the two others cut at the median among detected concentrations.

\subsubsection{Postnatal Exposure to Chlordecone}

A 5-ml sample of breast milk was obtained by manual pressure on the breast at the 3 months postnatal visit from 68 out of 75 nursing mothers. Milk samples were frozen at $-30^{\circ} \mathrm{C}$ and transferred on dry ice to Liege University for organochlorine analysis as previously described (Debier et al. 2003). The LOD for chlordecone in breast milk was $0.34 \mu \mathrm{g} / \mathrm{L}$. Milk lipid concentrations were quantified by gravimetry (Debier et al. 2003).

A variable describing postnatal chlordecone exposure through breastfeeding was created in 4 categories combining duration of breast feeding ( $<3$ months; $\geq 3$ months) and tertiles of chlordecone concentration in breast milk as following: 0 . no or less than 3 months breast feeding; 1. breast feeding at 3 months and chlordecone concentration $<0.50 \mathrm{ng} / \mathrm{ml} ; 2$. breast feeding at 3 months and chlordecone concentration $>0.50 \mathrm{ng} / \mathrm{ml}$ and $<0.90 \mathrm{ng} / \mathrm{ml} ; 3$. breast 
feeding at 3 months and chlordecone concentration $\geq 0.90 \mathrm{ng} / \mathrm{ml}$. A value equal to the median concentration of chlordecone measured in breast milk was imputed to the infants breast fed at 3 months for whom samples were not available $(n=7)$. The category 1 that includes infants breast fed up to 3 months with a low chlordecone concentration in breast milk was chosen as the reference category.

\subsection{Thyroid Hormone Analysis}

A $3 \mathrm{~mL}$ blood sample was obtained from infants after local anaesthesia, processed and frozen at $-30^{\circ} \mathrm{C}$ until shipment on dry ice to Rennes University Hospital for analysis. Due to limited serum volume, a priority order was introduced in the hormone determinations and not all hormones were measured in each sample. One child whose mother declared using medication for thyroid disease during pregnancy was excluded. This left 111 infants out of 148 for whom thyroid hormones were measured.

TSH, FT3 and FT4 levels were determined by chimiluminescent assays on the automated ADVIA-Centaur XP (Siemens Healthcare Diagnostics, Tarrytown NY, USA). Results were expressed as concentrations (unit of milli-international units per liter for TSH, unit of picogram per milliliter for FT3 and FT4). The intra- and inter-assay coefficients of variation were $<2.5$ and $<3.1,<5.3$ and $<4.1$, and $<4.7$ and $<5.8 \%$ for TSH, FT3 and FT4, respectively.

Hemolysis was present in several samples and the degree of hemolysis was ranked by visual inspection according to two levels (no or light hemolysis; moderate or strong hemolysis). Levels of TSH, FT3 and FT4 appeared to be influenced by the presence of hemolysis and by storage duration as previously reported (Panesar and Lit 2010). These characteristics of the samples were systematically taken into account in data analysis. 


\subsection{Assessment of infant neurodevelopment}

Among the 111 infants for whom thyroid hormone status was assessed at 3 months, 75 were part of a later assessment conducted at 18 months (Boucher et al. 2013) using an adapted version of the Ages and Stages Questionnaire, a screening test aimed at identifying children at risk for developmental delay (Bricker and Squires 1999). Each item from the communication, problemsolving, fine motor and gross motor areas of both the 18- and the 20-month questionnaires was administered directly to the child by a trained research personnel. A total score was calculated for each area by adding the points obtained by the child. All scores were then converted to Intelligence Quotient (IQ)-like scores, with a mean of 100 and a SD of 15.

\subsection{Statistical analysis}

Multiple linear regression models were used to evaluate the relation between exposure to chlordecone, TSH and thyroid hormone levels. To satisfy criteria of normality, TSH, FT3 and FT4 serum levels and concentrations of $p, p^{\prime}$-DDE and PCB-153 in cord blood were logtransformed (Ln). Thereby, results are expressed in percent change in hormone levels approximated by $\left(\mathrm{e}^{\text {beta coefficient }}-1\right) * 100$.

Maternal factors such as maternal age at delivery (years), years of education $(<12$ years; $\geq 12$ years), body mass index (BMI) before pregnancy ( $<25 \mathrm{~kg} / \mathrm{m} 2, \geq 25 \mathrm{~kg} / \mathrm{m} 2$ ), fish consumption during pregnancy (grams per day), and the child's birth weight z-score calculated from French reference curves (http://www.audipog.net/courbes_morpho.php) were considered a priori as susceptible to interfere in this association. Due to the limited sample size, we then tried to select the most parsimonious model using a manual backward selection to finally retain only variables 
significant at $20 \%$ level. We systematically forced adjustments for sex, hemolysis level and storage duration.

For each association with TSH, FT3, or FT4, three models were run including prenatal and postnatal exposure to chlordecone simultaneously since their correlation was moderate $(\mathrm{r}=0.20)$ : the first model adjusted for hemolysis, storage duration and sex; the second model additionally included maternal and child covariates selected according to the method described above; the third one additionally included the concentrations of $p, p$ '-DDE and PCB-153 and total lipids in cord blood. In this third model, cord concentrations of $p, p$ '- DDE or PCB-153 were treated as continuous variables since the shape of the association between cord concentrations of $p, p^{\prime}-$ DDE or PCB-153 in cord blood and 3-months thyroid hormone levels did not show any significant departure from linearity using generalized additive models (GAM). Values below LOD for $p, p^{\prime}$-DDE and PCB-153 were imputed using a distribution-based simple imputation method (proc Lifereg SAS, Jin et al. 2011).

For each hormone, results are presented for the overall sample and for each sex separately due to the known estrogenic activity of chlordecone. The shape of the associations between pre- or postnatal exposure to chlordecone and thyroid hormone levels (both in log scale) was further studied using GAM. The modeling relative to postnatal exposure was restricted to infants with a measure of breast milk chlordecone concentration (infants breast fed less than 3 months were excluded).

The association between chlordecone prenatal exposure, thyroid hormone levels at 3 months and ASQ scores at 18 months was studied using multiple linear regression models including sex, maternal level of education and child age at examination, co-variables retained in the original analysis (Boucher et al. 2013), now restricted to the sample $(n=75)$ for which we had simultaneously thyroid hormone levels at 3 months and ASQ scores at 18 months. The same 
association was then estimated with or without inclusion of the thyroid hormone levels in the models (adding hemolysis and storage duration as co-variables), to evaluate their potential role as intermediate factors, and for each sex separately as in the original analysis.

All analyses were performed using SAS 9.3.

\section{Results}

Sociodemographic and medical characteristics of mothers and infants are presented in Table 1. Most of the mothers were born in French West Indies, nearly half of them had more than 12 years of education, four out of ten were not living with their partner and about one quarter was overweight at the beginning of pregnancy. Only 9\% reported smoking, and $3.6 \%$ drinking alcohol during pregnancy. Two thirds of the infants were still breast fed at 3 months.

Chlordecone was detected in $59 \%$ of cord blood and $71 \%$ of breast milk samples. In cord blood, the median concentration of chlordecone $(0.13 \mu \mathrm{g} / \mathrm{L})$ was lower than the median concentration of $p$, ' $^{-}$DDE $(0.30 \mu \mathrm{g} / \mathrm{L})$ but slightly higher than the one of PCB-153 $(0.10 \mu \mathrm{g} / \mathrm{L})$. Concentrations of cord chlordecone concentration were moderately correlated with cord PCB$153(\mathrm{r}=0.24, \mathrm{p}<0.05)$ and cord $p, p^{\prime}-\mathrm{DDE}(\mathrm{r}=0.28, \mathrm{p}<0.05)$ and chlordecone in breast milk $(\mathrm{r}=0.20, \mathrm{p}<0.10)$. No correlation was observed between cord PCB-153 and $p, p$ '-DDE concentrations, or between both of these concentrations and chlordecone in breast milk (Supplementary Table A.1).

TSH, FT3 and FT4 levels (Supplementary Table A.2) are within normal range expected at 3 months (Kapelari et al. 2008).

Increase in TSH levels was observed in association with prenatal exposure to chlordecone, the percent change being higher in the medium range exposure, and limited to boys $(+89 \%$ 
$\mathrm{p}<0.006$ ) (Table 2). Adjustment for maternal confounders had minimal impact on estimates (Supplementary Tables A.3). PCB-153 and $p, p$ '- DDE concentrations were not significantly associated with TSH levels and their inclusion in the model induced minimal changes in estimates. GAM models suggest a linear relation between prenatal exposure to chlordecone and TSH (both on a log scale) whereas among girls TSH appears to increase with postnatal exposure and then levels off (Supplementary Figure A.1).

A decrease in the level of FT3 was observed in association with postnatal exposure to chlordecone, especially in the medium range $(-6.6 \% \mathrm{p}<0.03)$ (Table 3$)$, only slightly attenuated $(\mathrm{p}<0.06)$ when PCB-153 and $p, p^{\prime}-$ DDE concentrations were taken into account. Splines show a steady decrease of FT3 with increasing postnatal exposure among boys only (Supplementary Figure A.2). 
Finally a decrease in FT4 level associated with postnatal exposure to chlordecone was observed, but only among girls $(-11 \% \mathrm{p}<0.03)$ (Table 4$)$. Splines confirm the monotonic decrease of FT4 with increasing postnatal exposure among girls (Supplementary Figure A.3). In addition, prenatal exposure to $p, p$ '-DDE was negatively associated with FT4 level among boys $(\mathrm{p}<0.03)$ but this did not modify the associations with prenatal chlordecone exposure.

The association previously reported between higher prenatal chlordecone exposure and poorer ASQ fine motor score among boys in the same cohort remains of the same magnitude in the reduced sample (Table 5). When thyroid hormone levels are added to the model, a positive association between TSH level and ASQ fine motor score is observed in both sexes, but the inclusion of this variable does not modify the strength of the association between prenatal chlordecone exposure and ASQ fine motor score previously observed among boys. No association was observed between FT3 or FT4 levels and ASQ fine motor score (data not shown)

\section{Discussion}

We observed associations between perinatal exposure to chlordecone, TSH and thyroid hormone levels at 3 months, different according to the sex of the infant. Prenatal exposure to chlordecone was associated with an increase in the level of TSH in boys at 3 months, whereas postnatal exposure was associated with a decrease in FT3 mainly among boys, and in FT4 among girls. In addition, we observed that prenatal exposure to $p, p$ '- DDE was negatively associated with FT4 level among boys.

Our results suggest for the first time a potential impact of perinatal exposure to chlordecone on thyroid function in infants, with specificities according to sex. Although no experimental data 
are available to corroborate these findings, the impact of persistent organohalogens present in the environment on the thyroid hormone system is well recognized (Boas et al. 2012; Brouwer 1998). The differential associations according to the sex of the infant may be expected since chlordecone has well defined estrogenic properties (Hammond et al. 1979) and closely resembled circulating estrogen in its male-targeted effects on pituitary peptides (Hong et al. 1985). Indeed, both animals (Laessig et al. 2007; Mactutus and Tilson 1985) and human studies (Boucher et al. 2013) suggested sex-dependent behavioral and neurotoxic effects after prenatal or neonatal exposure to chlordecone

Although a positive association was observed between TSH levels and ASQ score of fine motor development, TSH level did not appear to modify the association between higher prenatal chlordecone exposure and poorer ASQ fine motor score. This suggests that chlordecone developmental neurotoxicity may be mediated by the estrogen signaling pathway rather than by the thyroid endocrine system or by an interaction between these two hormonal systems (Duarte-Guterman et al. 2014).

The main strength of this study is the longitudinal follow-up of perinatal exposure to chlordecone, thyroid hormones levels at 3 months and neurodevelopmental scores at 18 months, using biological measures of several other persistent contaminants. Children included in the survey were born at term, normal weight, with no birth defects, from a disease-free pregnancy. They were therefore not representative of the total newborn population and this excluded the possibility of appreciating the potential interaction of these conditions with chlordecone exposure on child thyroid dysfunction.

TSH and thyroid hormone levels were determined using standard methods available in clinical practice. Hemolysis and duration of storage had to be taken into account since they influenced circulating levels of FT3 and FT4 in particular, possibly as a result of destruction of thyroid- 
binding-globulin (Lingway and Holt 2012). TSH and thyroid hormone levels were measured away from birth at a moment more suitable for assessing infant's thyroid function than shortly after delivery (Boas et al. 2012). It may not however have been the optimal age or the most relevant hormone biomarkers (circulating hormone levels) to assess the putative link with later neurodevelopment, since increased TSH level at 3 months unexpectedly appears to be associated with better fine motor score at 18 months. A complete overview of a potential pathway of action of chlordecone on neurodevelopment through disruption of thyroid function would also require simultaneous assessment of maternal thyroid hormone levels during pregnancy, despite inherent difficulties in their measurement due to high variability across pregnancy.

Concentrations of chlordecone, $p p^{\prime}$-DDE and PCB-153 in cord blood provided an estimate of fetal exposure to these contaminants. Since breast milk samples were taken at 3 months, an estimate of cumulative intake of chlordecone through breast feeding was possible only for infants still breast fed at that time $(68 \%)$, the remaining $32 \%$ included both babies never breast fed and babies breastfed for a short time. To take into account the likely benefit of breast feeding in this analysis, the reference category was defined as infants breast fed at least 3 months with less contaminated milk.

Finally the small sample size limits the scope of these findings. This lack of power may explain why we did not observe the previously reported association between prenatal PCB-153 exposure and decrease in T3 or T4 levels in childhood, despite PCB-153 concentrations of the same order of magnitude than those reported in European birth cohorts (Govarts et al. 2012). We did however observe a decrease in FT4 level among 3-months old boys in association with $p, p^{\prime}$-DDE concentration in cord blood. Such an association was previously reported among newborns with similar levels of prenatal exposure to $p, p$ '-DDE by Maervoet et al. (2007) and 
Brucker-Davis et al. (2011), or in relation with much higher exposure in Thailand where decreased TT4 was observed (Asawasinsopon et al. 2006). This association has not however been reported by others (Alvarez-Pedrerol et al. 2008b; Darnerud et al. 2010; Schell et al. 2004; Steuerwald et al. 2000; Takser et al. 2005).

\section{Conclusions}

In conclusion, perinatal exposure to chlordecone may affect TSH and thyroid hormone levels at 3 months, differently according to the sex of the infant. Experimental work is needed to support these findings. 
Acknowledgments: We thank midwives and maternity staff at the University hospital of Pointe-à-Pitre and the General Hospital of Basse-Terre for collecting data. 
Table 1. Sociodemographic and medical characteristics of mothers and infants $(n=111)$

\begin{tabular}{cc}
\hline Characteristics & $\%$ or \\
& mean $\pm \mathrm{SD}$
\end{tabular}

\section{Maternal}

Age (years)

$30.7 \pm 6.8$

Birthplace (\% French West Indies)

80.2

Education ( $\% \geq 12$ years)

48.6

Marital status ${ }^{\text {a }}$

Alone

With a partner

Alone with family members

19.4

Parity

$1.1 \pm 1.2$

Maternal BMI $\left(\mathrm{kg} / \mathrm{m}^{2}\right)(\% \geq 25)$

26.1

Maternal weight gain during pregnancy (g/week) ${ }^{\mathrm{a}}$

$367 \pm 229$

Smoking during pregnancy (\% yes)

9.0

Alcohol drinking during pregnancy ${ }^{\mathrm{a}}$ (\% yes)

3.6

Fish consumption during pregnancy (g/day) ${ }^{\mathrm{a}}$

$130 \pm 153$

Infant

Age at (weeks)

$13.5 \pm 1.2$

Sex (\% male)

52.2

Gestational age (weeks)

$39.1 \pm 1.1$

Birth weight (g)

$3258 \pm 383$

Birth weight z-score

$0.1 \pm 0.9$

Breast-fed at 3 months (\% yes)

67.6 
SD: Standard Deviation; BMI: Body Mass Index

${ }^{a}$ Missing values for marital status ( $\left.n=3\right)$, maternal weight gain during pregnancy $(n=2)$, alcohol drinking during pregnancy $(n=1)$, fish consumption during pregnancy $(n=5)$. 
Table 2: Percent change in TSH (mIU/L) with prenatal exposure to chlordecone and exposure through breast feeding by sex

\begin{tabular}{|c|c|c|c|c|c|c|}
\hline Analyte $(\mu \mathrm{g} / \mathrm{L})$ & $\mathrm{N}$ & $\begin{array}{l}\text { Percent change } \\
\qquad(95 \% \mathrm{CI})^{\mathrm{a}}\end{array}$ & p-value & $\mathrm{N}$ & $\begin{array}{l}\text { Percent change } \\
\qquad(95 \% \mathrm{CI})^{\mathrm{b}}\end{array}$ & p-value \\
\hline \multicolumn{7}{|l|}{ Overall } \\
\hline \multicolumn{7}{|l|}{ Chlordecone in cord (class) } \\
\hline$<0.06$ & 46 & 0 & & 44 & 0 & \\
\hline $0.06-0.31$ & 36 & $50.7(17.2,93.9)$ & 0.002 & 35 & $46.8(10.8,94.3)$ & 0.008 \\
\hline$>0.31$ & 29 & $24.1(-4.8,61.8)$ & 0.11 & 27 & $24.7(-6.9,67.2)$ & 0.14 \\
\hline \multicolumn{7}{|l|}{ Chlordecone in milk (class) } \\
\hline Unexposed (breastfeeding $<3$ months) & 35 & $3.8(-21.9,37.9)$ & 0.80 & 35 & $7.6(-20.5,45.5)$ & 0.63 \\
\hline$<0.5$ & 25 & 0 & & 23 & 0 & \\
\hline $0.5-0.9$ & 26 & $30.0(-4.4,76.6)$ & 0.09 & 26 & $30.0(-6.8,80.9)$ & 0.12 \\
\hline$\geq 0.9$ & 24 & $17.5(-13.4,59.2)$ & 0.30 & 22 & $20.1(-13.5,66.7)$ & 0.27 \\
\hline $\ln$ PCB-153 & - & - & - & 106 & $0.01(-1.00,1.01)^{\mathrm{c}}$ & 0.99 \\
\hline $\ln p, p^{\prime}-\mathrm{DDE}$ & - & - & - & 106 & $-0.2(-0.82,0.04)^{c}$ & 0.55 \\
\hline \multicolumn{7}{|l|}{ Boys } \\
\hline \multicolumn{7}{|l|}{ Chlordecone in cord (class) } \\
\hline$<0.06$ & 18 & 0 & & 18 & 0 & \\
\hline $0.06-0.31$ & 23 & $93.7(30.7,186.9)$ & 0.001 & 22 & $89.3(21.3,195.6)$ & 0.006 \\
\hline$>0.31$ & 17 & $49.9(0.4,123.9)$ & 0.05 & 16 & $61.3(2.0,155.0)$ & 0.04 \\
\hline \multicolumn{7}{|l|}{ Chlordecone in milk (class) } \\
\hline Unexposed (breastfeeding $<3$ months) & 19 & $-3.1(-35.4,45.5)$ & 0.88 & 19 & $-1.6(-36.6,52.8)$ & 0.94 \\
\hline$<0.5$ & 14 & 0 & & 13 & 0 & \\
\hline
\end{tabular}




\begin{tabular}{|c|c|c|c|c|c|c|}
\hline $0.5-0.9$ & 14 & $24.6(-20.8,96.0)$ & 0.33 & 14 & $20.9(-26.6,99.2)$ & 0.45 \\
\hline$\geq 0.9$ & 11 & $7.6(-33.2,73.5)$ & 0.76 & 10 & $11.6(-35.0,91.6)$ & 0.68 \\
\hline $\ln$ PCB-153 & - & - & - & 56 & $-0.32(-1.93,1.27)^{c}$ & 0.68 \\
\hline $\ln p, p$ '-DDE & - & - & - & 56 & $0.04(-0.93,1.01)^{\mathrm{c}}$ & 0.94 \\
\hline \multicolumn{7}{|l|}{ Girls } \\
\hline \multicolumn{7}{|l|}{ Chlordecone in cord (class) } \\
\hline$<0.06$ & 28 & 0 & & 26 & 0 & \\
\hline $0.06-0.31$ & 13 & $18.1(-17.4,68.7)$ & 0.35 & 13 & $14.2(-24.3,72.5)$ & 0.52 \\
\hline$>0.31$ & 12 & $2.7(-28.3,47.1)$ & 0.88 & 11 & $-1.5(-35.7,51.1)$ & 0.95 \\
\hline \multicolumn{7}{|l|}{ Chlordecone in milk (class) } \\
\hline Unexposed (breastfeeding $<3$ months) & 17 & $20.8(-19.7,81.7)$ & 0.36 & 16 & $31.0(-16.6,105.4)$ & 0.23 \\
\hline$<0.5$ & 11 & 0 & & 10 & 0 & \\
\hline $0.5-0.9$ & 12 & $37.7(-10.1,111.1)$ & 0.14 & 12 & $41.8(-11.5,127.3)$ & 0.14 \\
\hline$\geq 0.9$ & 13 & $45.5(-3.1,118.6)$ & 0.07 & 12 & $47.4(-5.2,128.9)$ & 0.08 \\
\hline ln PCB-153 & - & - & - & 50 & $-0.27(-1.83,1.26)^{c}$ & 0.71 \\
\hline $\ln p, p^{\prime}-\mathrm{DDE}$ & - & - & - & 50 & $-0.03(-1.04,0.99)^{c}$ & 0.95 \\
\hline
\end{tabular}

TSH: Thyroid stimulating hormone; PCB: Polychlorinated biphenyl; DDE: dichlorodiphenyl

dichloroethylene

a: adjusted for hemolysis (no or weak, moderate or high), storage duration (continuous), (sex),

level of education (less than 12 years, at least 12 years)

b: additionally adjusted for $\ln$ PCB-153 (continuous), $\ln p, p$ '-DDE (continuous), total lipids

(continuous)

c: express in percent change in hormone levels for a $10 \%$ increase in exposure 
Table 3: Percent change in FT3 (pg/mL) with prenatal exposure to chlordecone and exposure through breast feeding by sex

\begin{tabular}{|c|c|c|c|c|c|c|}
\hline Analyte $(\mu \mathrm{g} / \mathrm{L})$ & $\mathrm{N}$ & $\begin{array}{l}\text { Percent change } \\
\qquad(95 \% \mathrm{CI})^{\mathrm{a}}\end{array}$ & $\mathrm{p}$-value & $\mathrm{N}$ & Percent change $(95 \% \mathrm{CI})^{\mathrm{b}}$ & p-value \\
\hline \multicolumn{7}{|l|}{ Overall } \\
\hline \multicolumn{7}{|l|}{ Chlordecone in cord (class) } \\
\hline$<0.06$ & 46 & 0 & & 44 & 0 & \\
\hline $0.06-0.31$ & 36 & $3.3(-1.7,8.4)$ & 0.20 & 35 & $3.9(-1.6,9.5)$ & 0.17 \\
\hline$>0.31$ & 29 & $-0.7(-5.7,4.5)$ & 0.77 & 27 & $0.5(-4.9,6.3)$ & 0.85 \\
\hline \multicolumn{7}{|l|}{ Chlordecone in milk (class) } \\
\hline Unexposed (breastfeeding $<3$ months) & 36 & $-2.4(-7.5,3.0)$ & 0.37 & 35 & $-1.9(-7.3,3.7)$ & 0.50 \\
\hline$<0.5$ & 25 & 0 & & 23 & 0 & \\
\hline $0.5-0.9$ & 26 & $-6.6(-11.9,-0.8)$ & 0.03 & 26 & $-6.0(-11.8,0.1)$ & 0.06 \\
\hline$\geq 0.9$ & 24 & $-3.8(-9.3,2.0)$ & 0.20 & 22 & $-2.9(-8.7,3.3)$ & 0.36 \\
\hline $\ln$ PCB-153 & - & - & - & 106 & $-0.05(-0.23,0.14)^{c}$ & 0.62 \\
\hline $\ln p, p^{\prime}-\mathrm{DDE}$ & - & - & - & 106 & $-0.05(-0.16,0.08)^{c}$ & 0.47 \\
\hline
\end{tabular}




\begin{tabular}{|c|c|c|c|c|c|c|}
\hline \multicolumn{7}{|l|}{ Boys } \\
\hline \multicolumn{7}{|l|}{ Chlordecone in cord (class) } \\
\hline$<0.06$ & 18 & 0 & & 18 & 0 & \\
\hline $0.06-0.31$ & 23 & $6.3(-1.6,14.8)$ & 0.12 & 22 & $5.9(-3.0,15.4)$ & 0.19 \\
\hline \multicolumn{7}{|l|}{ Chlordecone in milk (class) } \\
\hline Unexposed (breastfeeding $<3$ months) & 19 & $-3.8(-11.1,4.1)$ & 0.32 & 19 & $-2.8(-10.7,5.8)$ & 0.50 \\
\hline$<0.5$ & 14 & 0 & & 13 & 0 & \\
\hline$\geq 0.9$ & 11 & $-5.5(-14.0,3.7)$ & 0.22 & 10 & $-4.5(-13.8,5.9)$ & 0.37 \\
\hline $\ln$ PCB-153 & - & - & - & 56 & $-0.03(-0.33,0.28)^{c}$ & 0.84 \\
\hline $\ln p, p^{\prime}-\mathrm{DDE}$ & - & - & - & 56 & $-0.11(-0.31,0.08)^{c}$ & 0.22 \\
\hline \multicolumn{7}{|l|}{ Girls } \\
\hline \multicolumn{7}{|l|}{ Chlordecone in cord (class) } \\
\hline$<0.06$ & 28 & 0 & & 26 & 0 & \\
\hline
\end{tabular}




\begin{tabular}{|c|c|c|c|c|c|c|}
\hline $0.06-0.31$ & 13 & $0.7(-5.4,7.3)$ & 0.81 & 13 & $1.8(-5.1,9.1)$ & 0.61 \\
\hline$>0.31$ & 12 & $-2.2(-8.2,4.2)$ & 0.48 & 11 & $-0.7(-7.7,6.8)$ & 0.84 \\
\hline \multicolumn{7}{|l|}{ Chlordecone in milk (class) } \\
\hline Unexposed (breastfeeding $<3$ months) & 17 & $-2.4(-9.0,4.8)$ & 0.50 & 16 & $-2.4(-9.5,5.3)$ & 0.53 \\
\hline$<0.5$ & 11 & 0 & & 10 & 0 & \\
\hline $0.5-0.9$ & 12 & $-6.3(-13.1,1.0)$ & 0.09 & 12 & $-5.0(-12.5,3.0)$ & 0.21 \\
\hline$\geq 0.9$ & 13 & $-2.3(-9.1,4.9)$ & 0.51 & 12 & $-1.4(-8.6,6.4)$ & 0.71 \\
\hline $\ln$ PCB-153 & - & - & - & 50 & $-0.06(-0.32,0.20)^{\mathrm{c}}$ & 0.64 \\
\hline $\ln p, p^{\prime}-\mathrm{DDE}$ & - & - & - & 50 & $-0.01(-0.18,0.16)^{\mathrm{c}}$ & 0.95 \\
\hline
\end{tabular}

FT3: Free tri-iodothyronine; PCB: Polychlorinated biphenyl; DDE: dichlorodiphenyl dichloroethylene

${ }^{a}$ adjusted for hemolysis (no or weak, moderate or high), storage duration (continuous), (sex)

${ }^{\mathrm{b}}$ additionally adjusted $\ln$ PCB-153 (continuous), $\ln p, p^{\prime}-\mathrm{DDE}$ (continuous), total lipids (continuous)

${ }^{\mathrm{c}}$ express in percent change in hormone levels for a $10 \%$ increase in exposure 
Table 4: Percent change in FT4 (pg/mL) with prenatal exposure to chlordecone and exposure through breast feeding by sex

\begin{tabular}{|c|c|c|c|c|c|c|}
\hline Analyte $(\mu \mathrm{g} / \mathrm{L})$ & $\mathrm{N}$ & $\begin{array}{l}\text { Percent change } \\
\qquad(95 \% \mathrm{CI})^{\mathrm{a}}\end{array}$ & p-value & $\mathrm{N}$ & $\begin{array}{c}\text { Percent change (95\% } \\
\text { CI) }{ }^{b}\end{array}$ & p-value \\
\hline \multicolumn{7}{|l|}{ Overall } \\
\hline \multicolumn{7}{|l|}{ Chlordecone in cord (class) } \\
\hline$<0.06$ & 46 & 0 & & 44 & 0 & \\
\hline $0.06-0.31$ & 36 & $-2.6(-8.6,4.0)$ & 0.43 & 35 & $0.6(-6.3,8.0)$ & 0.87 \\
\hline$>0.31$ & 29 & $2.3(-4.3,9.5)$ & 0.49 & 27 & $4.1(-3.2,12.0)$ & 0.28 \\
\hline \multicolumn{7}{|l|}{ Chlordecone in milk (class) } \\
\hline Unexposed (breastfeeding $<3$ months) & 35 & $-1.4(-8.1,5.9)$ & 0.70 & 35 & $-0.5(-7.7,7.1)$ & 0.89 \\
\hline$<0.5$ & 25 & 0 & & 23 & 0 & \\
\hline $0.5-0.9$ & 26 & $-4.9(-12.1,2.9)$ & 0.21 & 26 & $-4.6(-12.2,3.7)$ & 0.26 \\
\hline$\geq 0.9$ & 24 & $-2.7(-10.1,5.3)$ & 0.49 & 22 & $-3.1(-10.9,5.1)$ & 0.44 \\
\hline ln PCB-153 & - & - & - & 106 & $-0.14(-0.39,0.10)^{\mathrm{c}}$ & 0.25 \\
\hline $\ln p, p^{\prime}-\mathrm{DDE}$ & - & - & - & 106 & $-0.18(-0.34,-0.01)^{c}$ & 0.04 \\
\hline
\end{tabular}




\begin{tabular}{|c|c|c|c|c|c|c|}
\hline \multicolumn{7}{|l|}{ Boys } \\
\hline \multicolumn{7}{|l|}{ Chlordecone in cord (class) } \\
\hline$<0.06$ & 18 & 0 & & 18 & 0 & \\
\hline $0.06-0.31$ & 23 & $0.5(-9.2,11.3)$ & 0.92 & 22 & $4.2(-7.0,16.6)$ & 0.47 \\
\hline$>0.31$ & 17 & $2.3(-8.0,13.8)$ & 0.66 & 16 & $4.6(-6.9,17.6)$ & 0.43 \\
\hline \multicolumn{7}{|l|}{ Chlordecone in milk (class) } \\
\hline Unexposed (breastfeeding $<3$ months) & 19 & $1.8(-8.4,13.1)$ & 0.74 & 19 & $3.1(-7.9,15.3)$ & 0.57 \\
\hline$<0.5$ & 14 & 0 & & 13 & 0 & \\
\hline $0.5-0.9$ & 14 & $-1.0(-12.4,11.7)$ & 0.86 & 14 & $-2.5(-14.0,10.6)$ & 0.70 \\
\hline$\geq 0.9$ & 11 & $1.8(-10.7,16.0)$ & 0.79 & 10 & $4.6(-9.2,20.4)$ & 0.53 \\
\hline $\ln \mathrm{PCB}-153$ & - & - & - & 56 & $-0.10(-0.49,0.30)^{c}$ & 0.63 \\
\hline $\ln p, p^{\prime}-\mathrm{DDE}$ & - & - & - & 56 & $-0.31(-0.57,-0.03)^{c}$ & 0.03 \\
\hline \multicolumn{7}{|l|}{ Girls } \\
\hline \multicolumn{7}{|l|}{ Chlordecone in cord (class) } \\
\hline$<0.06$ & 28 & 0 & & 26 & 0 & \\
\hline
\end{tabular}




$\begin{array}{lcccccc}0.06-0.31 & 13 & -1.5(-9.7,7.5) & 0.73 & 13 & -0.6(-10.1,10.0) & 0.91 \\ >0.31 & 12 & 2.0(-6.6,11.5) & 0.65 & 11 & 1.1(-9.1,12.4) & 0.84 \\ \text { Chlordecone in milk (class) } & & & & & \\ \text { Unexposed (breastfeeding<3 months) } & 17 & -7.5(-16.1,1.9) & 0.11 & 16 & -6.9(-16.6,4.0) & 0.20 \\ <0.5 & 11 & 0 & & 10 & 0 & 0.08 \\ 0.5-0.9 & 12 & -\mathbf{- 1 1 . 0}(-\mathbf{1 9 . 9}, \mathbf{- 1 . 2}) & \mathbf{0 . 0 3} & 12 & -10.0(-19.9,1.2) \\ \geq 0.9 & 13 & -9.3(-18.1,0.3) & 0.06 & 12 & -9.8(-19.2,0.7) & 0.07 \\ \ln \text { PCB-153 } & - & - & - & 50 & 0.04(-0.37,0.45)^{c} & 0.84 \\ \ln p, p^{\prime}-\mathrm{DDE} & - & - & - & 50 & -0.04(-0.30,0.21)^{c} & 0.74\end{array}$

FT4: Free thyroxine; PCB: Polychlorinated biphenyl; DDE: dichlorodiphenyl dichloroethylene

${ }^{a}$ adjusted for hemolysis (no or weak, moderate or high), storage duration (continuous), (sex), maternal age (continuous), fish consumption (continuous)

${ }^{\mathrm{b}}$ additionally adjusted for $\ln \mathrm{PCB}-153$ (continuous), $\ln p, p^{\prime}$-DDE (continuous), total lipids (continuous)

${ }^{\mathrm{c}}$ express in percent change in hormone levels for a $10 \%$ increase in exposure 
Table 5: Linear regression coefficients of ASQ fine motor score at 18 months and prenatal exposure to chlordecone ( $\mu$ g/L) with or without TSH level at 3 months

\begin{tabular}{|c|c|c|c|c|c|c|c|c|c|}
\hline Analyte & $\mathrm{N}$ & $\beta(95 \% \mathrm{CI})^{\mathrm{a}}$ & p-value & $\mathrm{N}$ & $\beta(95 \% \mathrm{CI})^{\mathrm{b}}$ & p-value & $\mathrm{N}$ & $\beta(95 \% \mathrm{CI})^{\mathrm{c}}$ & p-value \\
\hline \multicolumn{10}{|l|}{ Overall } \\
\hline \multicolumn{10}{|c|}{ Chlordecone in cord (class) } \\
\hline$<0.06 \mu \mathrm{g} / \mathrm{L}$ & 65 & 0 & & 31 & 0 & & 31 & 0 & \\
\hline $0.06-0.24 \mu \mathrm{g} / \mathrm{L}$ & 39 & $1.8(-4.3 ; 7.9)$ & 0.56 & 19 & $0.03(-9.2 ; 9.2)$ & 0.99 & 19 & $-2.0(-11.7 ; 7.6)$ & 0.68 \\
\hline$>0.24 \mu \mathrm{g} / \mathrm{L}$ & 44 & $-7.7(-13.6 ;-1.8)$ & 0.01 & 25 & $-7.3(-16.0 ; 1.3)$ & 0.09 & 25 & $-7.6(-17.3 ; 2.1)$ & 0.12 \\
\hline $\log \mathrm{TSH}(\mathrm{mlU} / \mathrm{L})$ & - & - & - & - & - & - & - & $8.3(0.6 ; 16.0)$ & 0.03 \\
\hline \multicolumn{10}{|l|}{ Boys } \\
\hline \multicolumn{10}{|c|}{ Chlordecone in cord (class) } \\
\hline$<0.06 \mu \mathrm{g} / \mathrm{L}$ & 25 & 0 & & 9 & 0 & & 9 & 0 & \\
\hline $0.06-0.24 \mu \mathrm{g} / \mathrm{L}$ & 18 & $0.8(-9.4 ; 11.0)$ & 0.88 & 11 & $-3.5(-21.9 ; 14.8)$ & 0.70 & 11 & $-7.4(-25.8 ; 11.0)$ & 0.41 \\
\hline$>0.24 \mu \mathrm{g} / \mathrm{L}$ & 23 & $-10.1(-19.4 ;-0.8)$ & 0.03 & 15 & $-14.0(-30.6 ; 2.6)$ & 0.09 & 15 & $-13.8(-31.2 ; 3.7)$ & 0.12 \\
\hline $\log \mathrm{TSH}(\mathrm{mlU} / \mathrm{L})$ & - & - & - & - & - & - & - & $10.9(-1.3 ; 23.2)$ & 0.08 \\
\hline
\end{tabular}




\begin{tabular}{|c|c|c|c|c|c|c|c|c|c|}
\hline \multicolumn{10}{|l|}{ Girls } \\
\hline \multicolumn{10}{|c|}{ Chlordecone in cord (class) } \\
\hline$<0.06 \mu \mathrm{g} / \mathrm{L}$ & 40 & 0 & & 22 & 0 & & 22 & 0 & \\
\hline $0.06-0.24 \mu \mathrm{g} / \mathrm{L}$ & 21 & $1.6(-6.4 ; 9.6)$ & 0.69 & 8 & $0.4(-10.7 ; 11.4)$ & 0.95 & 8 & $-1.7(-13.7 ; 10.2)$ & 0.77 \\
\hline$>0.24 \mu \mathrm{g} / \mathrm{L}$ & 21 & $-5.5(-13.3 ; 2.4)$ & 0.17 & 10 & $-1.1(-11.3 ; 9.0)$ & 0.82 & 10 & $-2.3(-14.1 ; 9.6)$ & 0.70 \\
\hline $\log \mathrm{TSH}(\mathrm{mlU} / \mathrm{L})$ & - & - & - & - & - & - & - & $8.0(-2.5 ; 18.5)$ & 0.13 \\
\hline
\end{tabular}

${ }^{a}$ Adjusted for maternal educational level (less than 12 years, at least 12 years), child age (continuous), (sex). Estimated from $n=148$ children with measures of cord Chlordecone and ASQ fine motor.

${ }^{b}$ Same model as (a) but estimated from the subgroup of $n=75$ children with measure of TSH

${ }^{\mathrm{c}}$ Same subgroup as (b) adjusted for maternal educational level (less than 12 years, at least 12 years), child age (continuous), (sex), hemolysis (no or weak, moderate or high), storage duration (continuous) 


\section{References}

Alvarez-Pedrerol M, Ribas-Fitó N, Torrent M, Carrizo D, Garcia-Esteban R, Grimalt JO, et al. 2008a. Thyroid disruption at birth due to prenatal exposure to betahexachlorocyclohexane. Environ Int 34:737-40.

Alvarez-Pedrerol M, Ribas-Fitó N, Torrent M, Carrizo D, Grimalt JO, Sunyer J. 2008b. Effects of PCBs, p,p'-DDT, p,p'-DDE, HCB and beta-HCH on thyroid function in preschool children.Occup Environ Med 65:452-7.

Asawasinsopon R, Prapamontol T, Prakobvitayakit O, Vaneesorn Y, Mangklabruks A, Hock B. 2006. The association between organochlorine and thyroid hormone levels in cord serum: a study from northern Thailand. Environ Int 32:554-9.

Bernert JT, Turner WE, Patterson DG Jr, Needham LL. 2007. Calculation of serum total lipid concentrations for the adjustment of persistent organohalogen toxicant measurements in human sample. Chemosphere 68:824-31.

Boas M, Feldt-Rasmussen U, Main KM. 2012. Thyroid effects of endocrine disrupting chemicals. Mol Cell Endocrinol 355:240-8.

Boucher O, Simard MN, Muckle G, Rouget F, Kadhel P, Bataille H, et al. 2013. Exposure to an organochlorine pesticide (chlordecone) and development of 18-month-old infants. Neurotoxicology 35:162-8. 
Bricker D, Squires J. 1999. Ages and Stages Questionnaire (ASQ): A parent-completed, child monitoring system, 2nd edition. Baltimore, MD: Paul H. Brookes Publishing.

Brouwer A, Morse DC, Lans MC, Schuur G, Murk AJ, Klasson-Wehler E, et al. 1998. Interactions of persistent environmental organohalogens with the thyroid hormone system: mechanisms and possible consequences for animal and human health. Toxicol Ind Health 14:59-84.

Brucker-Davis F. 1998. Effects of environmental synthetic chemicals on thyroid function. Thyroid 8:827-56.

Brucker-Davis F, Ferrari P, Boda-Buccino M, Wagner-Mahler K, Pacini P, Gal J, et al. 2011. Cord blood thyroid tests in boys born with and without cryptorchidism: correlations with birth parameters and in utero xenobiotics exposure. Thyroid 21:1133-41.

Cannon SB, Veazey JM Jr, Jackson RS, Burse VW, Hayes C, Straub WE, et al. 1978. Epidemic kepone poisoning in chemical workers. Am J Epidemiol 107:529-537.

Chevrier J, Eskenazi B, Bradman A, Fenster L, Barr DB. 2007. Associations between prenatal exposure to polychlorinated biphenyls and neonatal thyroid-stimulating hormone levels in a Mexican-American population, Salinas Valley, California. Environ Health Perspect 115:14906. 
Dallaire R, Dewailly E, Ayotte P, Muckle G, Laliberté C, Bruneau S. 2008. Effects of prenatal exposure to organochlorines on thyroid hormone status in newborns from two remote coastal regions in Québec, Canada. Environ Res 108:387-92.

Dallaire R, Muckle G, Dewailly E, Jacobson SW, Jacobson JL, Sandanger TM, et al. 2009. Thyroid hormone levels of pregnant inuit women and their infants exposed to environmental contaminants. Environ Health Perspect 117:1014-20.

Darnerud PO, Lignell S, Glynn A, Aune M, Törnkvist A, Stridsberg M. 2010. POP levels in breast milk and maternal serum and thyroid hormone levels in mother-child pairs from Uppsala, Sweden. Environ Int 36:180-7.

Debier C, Pomeroy PP, Dupont C, Joiris C, Comblin V, Le Boulenge E, et al. 2003. Quantitative dynamics of PCB transfer from mother to pup during lactation in UK grey seals Halichoerus grypus. Mar Ecol Prog Ser 247:237-48.

Duarte-Guterman P, Navarro-Martín L, Trudeau VL. 2014. Mechanisms of crosstalk between endocrine systems: Regulation of sex steroid hormone synthesis and action by thyroid hormones. Gen Comp Endocrinol 203C:69-85.

Dubuisson C, Héraud F, Leblanc JC, Gallotti S, Flamand C, Blateau A, et al. 2007. Impact of subsistence production on the management options to reduce the food exposure of the Martinican population to Chlordecone. Regul Toxicol Pharmacol 49:5-16 
Govarts E, Nieuwenhuijsen M, Schoeters G, Ballester F, Bloemen K, de Boer M, et al. 2012. Birth weight and prenatal exposure to polychlorinated biphenyls (PCBs) and dichlorodiphenyldichloroethylene (DDE): a meta-analysis within 12 European Birth Cohorts. Environ Health Perspect 120:162-70.

Hammond B, Katzenellenbogen BS, Krauthammer N, McConnell J. 1979. Estrogenic activity of the insecticide chlordecone (Kepone) and interaction with uterine estrogen receptors. Proc Natl Acad Sci U S A 76:6641-5

Herbstman JB, Sjödin A, Apelberg BJ, Witter FR, Halden RU, Patterson DG, et al. 2008. Birth delivery mode modifies the associations between prenatal polychlorinated biphenyl (PCB) and polybrominated diphenyl ether (PBDE) and neonatal thyroid hormone levels. Environ Health Perspect 116:1376-82.

Hong JS, Hudson PM, Yoshikawa K, Ali SF, Mason GA. 1985. Effects of chlordecone administration on brain and pituitary peptide systems. Neurotoxicology 6:167-82

Jin Y, Hein MJ, Deddens JA, Hines CJ. 2011. Analysis of Lognormally Distributed Exposure Data with Repeated Measures and Values below the Limit of Detection Using SAS. Annals of Occupational Hygiene 55:97-112.

Kapelari K, Kirchlechner C, Högler W, Schweitzer K, Virgolini I, Moncayo R. 2008. Pediatric reference intervals for thyroid hormone levels from birth to adulthood: a retrospective study. BMC Endocr Disord 27;8:15. 
Koopman-Esseboom C, Morse DC, Weisglas-Kuperus N, Lutkeschipholt IJ, Van der Paauw

CG, Tuinstra LG, et al. 1994. Effects of dioxins and polychlorinated biphenyls on thyroid hormone status of pregnant women and their infants. Pediatr Res 36:468-73.

Laessig SA, Auger AP, McCarthy MM, Silbergeld EK. 2007. Effects of prenatal chlordecone on sexually differentiated behavior in adult rats. Neurotoxicol Teratol 29:255-63.

Lingway I, Holt SA. 2012. The thyroid. In: Textbook of endocrine physiology (Kovacs WJ, Ojeda SR, eds). $6^{\text {th }}$ edition. New York: Oxford University Press, 311-345.

Longnecker MP, Gladen BC, Patterson DG Jr, Rogan WJ. 2000. Polychlorinated biphenyl (PCB) exposure in relation to thyroid hormone levels in neonates. Epidemiology 11:249-54.

Lopez-Espinosa MJ, Vizcaino E, Murcia M, Fuentes V, Garcia AM, Rebagliato M, et al. 2010. Prenatal exposure to organochlorine compounds and neonatal thyroid stimulating hormone levels. J Expo Sci Environ Epidemiol 20:579-88.

Mactutus CF, Tilson HA. 1985. Evaluation of long-term consequences in behavior and/or neural function following neonatal chlordecone exposure. Teratology 31:177-86.

Maervoet J, Vermeir G, Covaci A, Van Larebeke N, Koppen G, Schoeters G, et al. 2007. Association of thyroid hormone concentrations with levels of organochlorine compounds in cord blood of neonates. Environ Health Perspect 115:1780-6. 
Matsuura N, Uchiyama T, Tada H, Nakamura Y, Kondo N, Morita M, et al. 2001. Effects of dioxins and polychlorinated biphenyls (PCBs) on thyroid function in infants born in Japan-the second report from research on environmental health. Chemosphere 45:1167-71.

Multigner L, Ndong JR, Giusti A, Romana M, Delacroix-Maillard H, Cordier S, et al. 2010. Chlordecone exposure and risk of prostate cancer. J Clin Oncol 28:3457-62.

Osius N, Karmaus W, Kruse H, Witten J. 1999. Exposure to polychlorinated biphenyls and levels of thyroid hormones in children. Environ Health Perspect 107:843-9.

Panesar NS, Lit LC. 2010. Stability of serum thyroid hormones following 8-11 years of cold storage. Clin Chem Lab Med 48:409-412.

Ribas-Fitó N, Sala M, Cardo E, Mazón C, De Muga ME, Verdú A, et al. 2003.

Organochlorine compounds and concentrations of thyroid stimulating hormone in newborns. Occup Environ Med 60:301-3.

Schell LM, Gallo MV, Decaprio AP, Hubicki L, Denham M, Ravenscroft J, et al. 2004. Thyroid function in relation to burden of PCBs, p,p'-DDE, HCB, mirex and lead among Akwesasne Mohawk youth: a preliminary study. Environ Toxicol Pharmacol 18:91-9.

Steuerwald U, Weihe P, Jørgensen PJ, Bjerve K, Brock J, Heinzow B, et al. 2000. Maternal seafood diet, methylmercury exposure, and neonatal neurologic function. J Pediatr 136:599605. 
Takser L, Mergler D, Baldwin M, de Grosbois S, Smargiassi A, Lafond J. 2005. Thyroid hormones in pregnancy in relation to environmental exposure to organochlorine compounds and mercury. Environ Health Perspect 113:1039-45.

Wang SL, Su PH, Jong SB, Guo YL, Chou WL, Päpke O. 2005. In utero exposure to dioxins and polychlorinated biphenyls and its relations to thyroid function and growth hormone in newborns. Environ Health Perspect 113:1645-50.

Wilhelm M, Wittsiepe J, Lemm F, Ranft U, Krämer U, Fürst P, et al. 2008. The Duisburg birth cohort study: influence of the prenatal exposure to PCDD/Fs and dioxin-like PCBs on thyroid hormone status in newborns and neurodevelopment of infants until the age of 24 months. Mutat Res 659:83-92.

Zoeller TR, Dowling AL, Herzig CT, Iannacone EA, Gauger KJ, Bansal R. 2002. Thyroid hormone, brain development, and the environment. Environ Health Perspect 110 Suppl 3:35561. 